\title{
The Implementation of Educational Learning Services For The Penghayat Kepercayaan
}

\author{
*aseptian Aji Permana, bMohamad Maulana Magiman \\ aUniversitas PGRI Yogyakarta, Indonesia, \\ bDepartment of Social Science, Faculty of Agriculture and Food Science, Universiti Putra Malaysia Bintulu \\ Campus, Sarawak, Malaysia \\ Corresponding Author Email: *aji@upy.ac.id
}

\begin{abstract}
Indonesia is a multicultural country with various religions, ethnicities, races, languages, and cultures. In total, there are seven religions recognised by the Indonesian government which are Islam 207,176,162, Christian 16,528,513, Catholic 6,907,873, Hinduism 4,012,116, Buddhism 1,703,254, Kong $\mathrm{Hu}$ Chu 117,091, and penghayat kepercayaan 1,198,031. Penghayat kepercayaan is considered the main religion for their number of followers in Indonesia, but the teachers do not have policy regulations of education by the law. The school autonomy policy governs the rules in schools for the students that believe in penghayat kepercayaan. N 1 Kasihan implements an integrated education system by collaborating with trusted leaders to become a teacher. This research aimed to study the Indonesian government's policy on religious education for unofficial religious groups of penghayat kepercayaan (Belief in One God) and analysed the implementation on the fulfillment of educational learning services for penghayat kepercayaan believers by education authorities in Bantul. This research was conducted using a qualitative approach. The participants of this study were the Bantul education authorities, students who believe in penghayat kepercayaan, and the curriculum's deputy. Data collection techniques were done through participant observation and in-depth interviews. The collected data were analysed using domain analysis techniques. The results of this study indicated Indonesian government's policy on education for penghayat kepercayaan believers are already regulated in the Regulation of the Minister of Education and Culture of Republic of Indonesia Number 27 in 2016 on Educational Services for aliran kepercayaan on Education Unit, and the implementation of education learning service. The students associated with penghayat kepercayaan in the Vocational High School in Bantul, Indonesia (SMK N 1 Kasihan) have not been fully accommodated due to the irrelevant teachers' qualifications penghayat kepercayaan.
\end{abstract}

Keywords - Policy, Faith, Education, Learning, Indonesia Footnote- Aliran kepercayaan (Belief in One God) is unofficial religious groups in Indonesia, penghayat kepercayaan (persons who practise the aliran kepercayaan)

\section{INTRODUCTION}

Article 5 paragraph 1 of Regulation Number 20 the Year 2003 concerning the National Education System confirms that every citizen has the equal right to access quality education. In article 5 paragraph 3 , the Regulation also explains that remote areas have the right to get exceptional service in education.

The issue of religious education in Regulation Number 20 the Year 2003 concerns the National Education System in article 12 paragraph 1, which explains that every student in each educational unit is entitled to receive religious education. It is based on their religion and is taught by educators who follow the teaching of religion. Besides, students also deserve to have 
access to educational rights in improving their talents, interests, and abilities.

Penghayat Kepercayaan Kepada Tuhan Yang Maha Esa (Belief in One God) or Penghayat Kepercayaan is a term given by the Indonesian government because of the difficulties in defining the official and unofficial religion in Indonesia. The beliefs that are not from the six official religions in Indonesia, such as Islam, Catholicism, Christianity, Buddhism, Hinduism, and Confucianism, are considered non-official or unofficial religions.

The believers of Penghayat Kepercayaan are those who acknowledge and accept the values of believers in God Almighty. It is the expression and execution of a personal relationship with the God Almighty based on the conviction created by righteous behaviour and worshipping God Almighty and practice of nobility whose teachings derived from local wisdom (Widya, Dita. 2017; Zakiyah. 2018)

In general, education is an effort to strengthen the character building, which includes inner strength, character, and thoughts of the learners. Education can also shape the perfect life to harmony with the world. It can be interpreted that education is an effort to improve the character, mind, and body of the learners, so they can extend their life and raise children in harmony with nature and society (Maureen Hannay, Tracy Newvine. 2006; Kang'ahi, M., Indoshi, FC, Okwach, TO \& Osodo, J. 2012).

Education is compulsory for every human as an effort to humanise the humans. Every citizen of the Republic of Indonesia deserves to have a proper education based on article 31 of the 1945 Constitution. The matters related to education are regulated in legislation mandated by the government as the Act's executor. It is expected that all Indonesian citizens will access the right to education. The government is responsible for the implementation of a compulsory education program, which is the minimum standard of education that must be accomplished by every citizen of the country (Muwaffiq and Mukhlish, 2019).

Religious education has a crucial role in shaping morals because religion regulates human relations with God, between each other, and nature, which ensure the balance of harmony in human life as individuals and the members of society.

In this case, the government of Indonesia produced regulations specifically for religious education, which is the Government Regulation Number 55 the Year 2007. In the regulation, religious education provides the knowledge, attitudes, personalities, and skills of students in practising their spiritual teachings. Religious education must also be known as a character builder and the moral foundation of their conduct. It can be interpreted that religious education is also related to the character-building of students (Thomas Lickona, 2013; Muwaffiq and Mukhlish. 2019).

Recently in Bantul, there are two students that practice penghayat kepercayaan. Therefore, the government should take this into account to avoid the sense of discrimination caused by the distinct belief which is different from the other official religions such as Islam, Christian, Catholic, Hinduism, Buddhism, and Confucianism. The government should provide adequate facilities and teachers as the other official religions received. However, the finding found the unequal service, and the students are taught by a teacher who is not from the community of penghayat kepercayaan (Turner, E.A., Chandler, M., \& Heffer, R.W. 2009; Widya, Dita. 2017; Zakiyah. 2018).

The religious education service in the education unit has been regulated by the Regulation of Ministry of Education and Culture of the Republic of Indonesia Number 272016. Hence, the government has set the regulation that every religion has equal service, which is supposed to prevail to the students that believe in penghayat kepercayaan.

By the mandate of the Preamble of 1945 Constitution of the Republic of Indonesia, which is to educate the nation's life, the country must carry out its obligations in fulfilling the right of 
education for the penghayat kepercayaan believers in providing education equally with the other citizens. There is no discrimination for the student of penghayat kepercayaan in every aspect of learning.

Based on the previous explanation, religious education is critical in every unit of education to build the character and morals of the student. Besides, it is not an exception for the students of penghayat kepercayaan because they have the same right to obtain an education.

\section{RELEVANT LITERATURE DEFINITION OF PENGHAYAT KEPERCAYAAN}

Zakiyah (2018) has research entitled 'Education of belief in God Almighty: Fulfillment of the Rights of Penghayat Students in the School,' which explains that the students of penghayat kepercayaan still experience discrimination, especially in term of respecting civil rights.

This case is rooted in 'differences' happen from the recognition of religion-state and different treatment between 'religion' and 'belief.' In the Joko Widodo-Jusuf Kalla government, the main agendas is prioritizing the protection of children, women, and marginalised community groups. Besides, it includes respect for human rights and equitable resolution of previous cases of human rights violations. It is to provide the right momentum for the enforcement of human rights.

The question is 'how is the implementation of respect for human rights towards the penghayat kepercayaan believers in Bandung city?'. Therefore, the study is carried out based on descriptive-analytical research with a normative juridical approach at the implementation level (especially the City of Bandung). The penghayat kepercayaan believers have no problems in obtaining civil rights and registration. However, there still rejection from public society about the burial of the penghayat kepercayaan believers in a public cemetery. The refusal certainly contradicts Article 8 paragraph (2) of Joint Regulation of the Minister of Home Affairs, and the Minister of Culture and Tourism Number 43 the Year 2009 and Number 41 the Year 2009 concerning Guidelines of Civil Service. It initiated the regional government to provide a public cemetery for the penghayat kepercayaan believers to worship God Almighty.

Widya Dita (2017) discussed the legal protection for penghayat kepercayaan from blasphemy. She found that there were still many religious sects of many different beliefs in Indonesia that were passed by the ancestors. However, these aliran kepercayaan (unofficial religious sects) have not received maximum legal protection from the state.

Article 28E and Article 29 paragraph (1) of the 1945 Constitution of the Republic of Indonesia has explicitly stated that the state will guarantee freedom for all citizens in practising their beliefs. It is mentioned on the warranty has no exception.

Aliran Kepercayaan has the right to get legal protection that does not contain discrimination against their religious practices. Therefore, based on the previous explanation, the writer formulates the problem: 1) What is the urgency of the regulation regarding the protection of penghayat kepercayaan from religious blasphemy against their beliefs? 2) How to manage the protection of their beliefs from religious blasphemy? The purpose of this research is to provide benefits and contributions related to legal protection arrangements for Aliran Kepercayaan, penghayat kepercayaan, community, and the related parties involved, including the legal practitioners (Tella, J., Indoshi, F. C. \& Othuon, L. A. 2010).

Tella's research (2010) employed legal (normative juridical) research with a statutory approach. Primary and secondary legal entities will be analysed descriptively to find the general in nature. Accordingly, they are categorised and systematically arranged.

From that point, the reasons for the urgency of legal protection arrangements for aliran kepercayaan should be established. Hence, new legal concepts can be formed through the legal protection for aliran kepercayaan in Indonesia. It is widely acknowledged that religious 
freedom is an absolute right of every citizen. It does not matter, even if it is from a group of penghayat kepercayaan or official religious communities in Indonesia (Frietas, K.S. \& Lynch, P. 1986; Dian, Kurnia, 2018).

One of the articles in the Constitution Journal 'Akibat Hukum Pemisahan Hak Beragama dengan Hak Berkepercayaan dalam Undang-Undang Dasar Negara Republik Indonesia Tahun 1945' or The Legal Effects of the Separation of the right of practising religion for kepercayaan in 1945 Constitution of Republic of Indonesia) written by Muwaffiq and Mukhlis (2019). The writers mentioned that the separation of religion and aliran kepercayaan in the constitution could trigger a series of problems.

Frequently penghayat kepercayaan experienced intimidation or other things that disrupt their civil rights to embrace and practice their beliefs. Since the perpetrators of anarchism believe that aliran kepercayaan is not a religion, they frequently prohibit and commit violence against penghayat kepercayaan believers.

This study applies normative legal research methods. Meanwhile, results of the research are: 1) The legal reason for the separation of arrangement between religion and aliran kepercayaan is caused by the politics of the distinct definition of both terms; Aliran Kepercayaan represents a noble tradition and teachings of the community which originates from a culture outside of religion. 2) Separation of religion and kepercayaan legally resulted in the unrecognition aliran kepercayaan as an official religion of the state, even though aliran kepercayaan considered a local belief to be a religion by the followers.

This separation also results in the presence of various discriminatory attitudes that have the potential to interfere and deprive the rights of every citizen in practising a religion. In this case, the religious rights that are disturbed and deprived are the right to believe in local religion as a religion of Indonesian ancestral heritage (Muwaffiq, and Mukhlish. 2019).

\subsection{DEFINITION OF LEARNING}

Learning is the teacher's activities programmed in instructional design to make active learning that emphasises learning resources. The concept of learning is a process of a person's environment intentionally managed to enable someone to participate in certain behaviours in particular conditions that produce responses to certain situations. Learning is an activity designed to help someone learn a new ability and value.

\subsection{POLICY ON RELIGIOUS EDUCATION IN INDONESIA}

Generally, educational regulations in Indonesia have been regulated in the National Education System Law No. 20 of 2003. Meanwhile, religious education is contained in Article 30 , paragraph 1 , in which religious education is carried out by the government and community groups of religious followers by statutory regulations. Religious education functions to prepare students to become community members who can understand or practice the values of their spiritual teachings or become experts in theology, which is contained in paragraph 2. As explained in paragraph 3 , religious education can be held in non-formal and informal education paths.

2 Religious education is further regulated in Government Regulation No. 55/2007 concerning Religious Education. In Article 2, the regulation states that religious education functions to form Indonesian people who believe in and fear God Almighty, to have good character, and can maintain peace and harmony in interreligious relations. Religious education aims to develop the ability of students to understand, live, and practice religious values that harmonise their mastery in science, technology, and art. It is more clarified 


\section{in Article 3 of the regulation that states every education unit in all lines, levels, and types of education are required to organise religious education.METHOD}

\subsection{RESEARCH DESIGN}

This research employs a qualitative approach. This research was conducted at SMK Negeri 1 Kasihan, Yogyakarta. The informants of this research were the Bantul Education Office, students of penghayat kepercayaan, the deputy of the curriculum. The technique for determining the informant was done by snowball sampling. Data collection instruments were in the form of observation (in a participatory, frank and disguised, and unstructured), interviews (using descriptive questions, structural questions, and contrast questions), and documentation.

Data analysis techniques applied taxonomic analysis techniques by organising and reducing data into patterns, categories, and fundamental units of the description so that themes can be determined and conclusions can be formulated. Analysis of the Culture Theme was carried out at the time of data collection and after the completion of data collection. The analytical work carried out, in this case, was to organise, sort, code, and categorise data so that a description can be found that matches the aspects under study.

\subsection{PROCEDURE}

Technical analysis in this research takes place continuously until complete and interactive. Activities in analysing data are data reduction, data display, and conclusion drawing or verification.

\section{$2.3 \quad$ INPUT}

1) The Indonesian government's religious education policy towards unofficial religious groups of penghayat kepercayaan (Belief in One God).

2) Implementation of the fulfillment of educational learning services for the penghayat kepercayaan by the education authorities in Bantu

\subsection{PROCESS}

The stages used in the study to support the validity of the data are as follows:

1) Credibility (internal validity) is a test of trust in the data of research results by triangulation of data sources using various data sources such as documents, archives, interviews, observations on different subjects. Triangulation techniques that use a variety of data collection techniques to ensure data already meet the established accountability requirements.

2) Transferability is an external validity test that shows the accuracy of the study results to the sample population taken.

3) Dependability (dependency) is a test conducted by an audit of the entire research process.

4) Confirmability, namely the test of research results that are linked to the process carried out, if the results of the research are a function of the research process, the research meets the standards.

\subsection{OUTPUT}


The results of this study indicate the Indonesian government's education policy for penghayat kepercayaan has regulated in the Regulation of the Minister of Education and Culture of Republic of Indonesia Number 27 of 2016 on Educational Services for aliran kepercayaan on education unit and the implementation of education learning service for penghayat kepercayaan.

\subsection{DESIGN VALIDITY}

Design validity in this study are as the following:

1) To reduce the data in this study by grouping the data needed for research.

2) Display data after the data has been reduced, and the next step is to present the data. The presentation uses a narrative text.

3) To conclude, the picture of an object that still unclear, so after examination, becomes apparent in the form of a hypothesis.

\section{RESULT}

\subsection{RESEARCH DATA}

In 2016, after the issuance of an educational policy for penghayat kepercayaan in the Regulation of the Minister of Education and Culture of the Republic of Indonesia Number 27 of 2016 on Education Services Kepercayaan (belief) in God Almighty in Educational Unit.

The Minister of Education and Culture held a selection for teachers in religious education for penghayat kepercayaan in Bandung. 42 participants involved in the selection and all participants were representatives from each region. At the selection stage, there were 41 participants passed.

The stage after the selection is counselling, which can also be described as a quick lecture (fast) to become a teacher. Since most of the participants graduated outside of the education department (Bachelor of Education), it can be assumed that only 5 to 7 participants majoring in education (Bachelor of Education).

Counselling was concerned with core competencies and essential competencies of teaching, syllabus, lesson plan, and micro-teaching. After everything was done, the participants were given a certificate to sign that they have received a license from the Minister of Education and Culture as proof that they are officially qualified to be a teacher. Learning activities for penghayat kepercayaan students undertaken in the school library.

Four participants were representing Yogyakarta that representing several regions in Yogyakarta. First, they started teaching in 2017 at SMK Negeri 1 Kasihan until now. As expressed by the Teacher of Kepercayaan at the Vocational School 1 Kasihan, known as Triyani Yuliastuti, Thursday 19 September 2019 said:

"Pada tahun 2016 saya dan tiga teman yang mewakili Yogyakarta mengikuti seperti seleksi mengajar atau bisa dibilang menjadi guru kususnya guru pengajar pendidikan agama Penghayat Kepercayaan yang diadakan oleh Menteri Pedidikan dan Kebudayaan di Bandung. Peserta yang mengikuti ada 42 orang dan yang lolos 41 orang. Penyuluhan yang diberikan waktu itu bisa dibilang kuliah kilat ya mba. Jadi kami semua diajarkan cara membuat RPP, silabus, KI dan KD sama Micro Teaching, jadi bener-bener seperti kuliah jurusan pendidikan tapi cara kilat, malah saat itu belum diajarkan mengenai materinya. Rata- rata yang mengikuti seleksi ini bukan lulusan dari jurusan pendidikan, yang lulusan dari jurusan pendidikan $5-7$ orang saja mba, saya sendiri juga bukan lulusan pendidikan. Setelah selesai kami diberi sertifikat untuk tanda bukti bila nanti ada sekolah maupun luar sekolah yang membutuhkan seorang pengajar atau penyuluh pendidikan keagamaan kami sudah bersertifikat dan ada ijinnya. Saya sendiri diminta mengajar di SMK Negeri 1 Kasihan 2017 sampai saat ini". 
"In 2016, three other friends representing Yogyakarta and I took part in a teaching selection, or it could be said to be a teacher, especially a teacher of the religious education teacher for penghayat kepercayaan held by the Minister of Education and Culture in Bandung. 42 participants participated, and 41 passed. Counselling given at that time can be said as a quick lecture. So we were all taught how to make a lesson plan, syllabus, core competency, and standard competency of teaching and micro-teaching, so it was really like studying in a college. Still, it was a quick way. Even then, it was not taught about the material. On average, those who took part in this selection were not graduates from the education department, those who have graduated from the education department only 5 to 7 persons. I am not a graduate of education either. After completion, we were given a certificate for proof. If a school or outside school needs a teacher or extension, our religious education is already certified and has permission. I was asked to teach at SMK Negeri 1 Kasihan 2017 to date".

The Kepercayaan Education Curriculum is one of the fulfillments of learning services for penghayat kepercayaan students mentioned in Minister of Education and Culture Regulation Number 27 of 2016. Currently, the curriculum is still in the stage of improvement or revision. The curriculum has previously experienced improvements and is currently undergoing a revision. It impacts the material and textbooks as support and fulfillment of the learning services of penghayat kepercayaan. As said by the teacher of Vocational High School 1 Kasihan, Triyani Yuliastuti, Thursday, 19 September 2019 said:

"Saat ini kurikulum Pendidikan Penghayat Kepercayaan masih belum jelas mba, karena sudah berapa kali mengalami revisi dan sekarang masih dalam tahap revisi kembali. Hal ini juga yang menjadi kurang terpenuhinya pembelajaran bagi siswa. Untuk saat ini materi yang digunakan materi sebelum revisi sembari menunggu materi baru yang sesuai dengan kurikulum yang baru juga. Yang penting siswa tetap belajar dan tidak tertinggal materi".

"At present, the Curriculum for Education of penghayat kepercayaan students is still unclear because there have been revisions for several times, and now it is still in the revision stage. It also lacks the fulfillment of learning for students. We are using unrevised material while waiting for new material following the new curriculum as well. The important thing is the students keep learning and don't get left behind by the material".

\subsection{DISCUSSIONS}

Penghayat kepercayaan is one of the minorities in Indonesia. Hence, government policies related to penghayat kepercayaan, including state recognition, civil registration, legal marriage, and the policy on religious education for penghayat kepercayaan whose rights for penghayat kepercayaan require serious attention. The policy on religious education for students of penghayat kepercayaan has recently been issued. Nevertheless, education is one of the principal rights every citizen to fulfill by following the mandate of the opening of the 1945 Constitution of the Republic of Indonesia. It is to educate the nation's life and following Article 31 paragraph 1 of the 1945 Constitution, which states that every citizen has the right to get a proper education. Therefore, the state must carry out its duties in fulfilling the educational rights of penghayat kepercayaan to obtain religious education based on their beliefs.

Government policy on religious education only focuses on six official religions. The services for penghayat kepercayaan has been established since 2009, which is contained in the Joint Ministerial Regulation Number 43/41 of 2009 on The Services Guidelines for penghayat kepercayaan to worship the God Almighty. However, the policy of religious education service for penghayat kepercayaan was established in 2016, mentioned in the Regulation of the Ministry of Education and Culture of the Republic of Indonesia Number 27 th e Year 2016 on Educational Services penghayat kepercayaan to God Almighty at every educational unit. It can be interpreted that the government is irresponsive in taking action to straighten the problematic policies related to penghayat kepercayaan.

The Regulation of the Minister of Education and Culture of the Republic of Indonesia

$381 \mid \mathrm{P}$ a g e 
Number 27 the Year 2016 provides various regulations and rights of education and learning services for penghayat kepercayaan. One of the rules mentions the right to have qualified teachers (tutor) whose qualification is linear to Aliran Kepercayaan, proper curriculum, linear learning outcomes, syllabus, lesson plans, and textbooks.

To ensure the fulfillment of the service for penghayat kepercayaan, Central Government, Regional Governments, and education units (schools) should work together with the registered organisation of penghayat kepercayaan. The Policy of the Republic of Indonesia Minister of Education and Culture Regulation No. 27 the Year 2016 is quite clear about education services for students of kepercayaan. The established regulations, the fulfillment of the service is expected to be the real conditions of the students of penghayat kepercayaan.

The fulfillment of educational learning services for penghayat kepercayaan students in Bantul Education Office is stipulated in the Regulation of the Minister of Education and Culture of the Republic of Indonesia Number 27 the Year 2016 on education services for penghayat kepercayaan. It indicates that all aspects of educational services for penghayat kepercayaan must have been fulfilled and received by students of penghayat kepercayaan, including students of penghayat kepercayaan Bantul. In Bantul Education Office, there is a school that accepts students of penghayat kepercayaan, which is SMK Negeri 1 Kasihan (Vocational High School 1 Kasihan). There are two penghayat kepercayaan students who study at SMK Negeri 1 Kasihan.

Students of penghayat kepercayaan are registered at SMK Negeri 1 Kasihan in the 2019/2020 Academic Year. The school has accepted students well. The school has never forced the penghayat kepercayaan students to attend religious subjects in the school. The school has also moved quickly to find qualified teachers for the students, submitted the required data, and requested the Local Government to act further to make decisions and policies towards penghayat kepercayaan students.

The religious education subject (aliran kepercayaan education subject) did not run as expected. Although the Local Government has provided a teacher for aliran kepercayaan, the teacher did not have expertise in aliran kepercayaan (not a part of the Aliran Kepercayaan Community). The school and the students have requested the government to further act in solving this issue. Instead of making a wrong decision, the school has taken corrective action by waiting for the Local Government to carry out its duties. After six-month waiting, the school finally took action to solve the problem. The action should be taken to ensure the learning activities run well as expected. The learning activities of the subject had been undertaken in the Catholic education room and the school library.

To date, the curriculum of aliran kepercayaan subject is still in the stage of improvement. The students have to learn the existing curriculum thatdoes not correspond to their beliefs due to their unavailability. Accordingly, the textbooks and learning materials are also not relevant to the teaching of the aliran kepercayaan. From 10th grade to 12 th-gradestudents, the students of penghayat kepercayaan have never studied using relevant textbooks. The students only learn their religious education subject through online material sent by the teacher of penghayat kepercayaan via mobile phones. It is intended that their students can still learn and understand the material even in a limited circumstance. It does not mean that the school does not provide or find textbooks or learning material. The government has not yet issued or published the educational material of Aliran Kepercayaan in books.

In SMK N 1 Kasihan, the students and the teacher of penghayat kepercayaan come from a different community of penghayat kepercayaan. The two students are from Palang Putih Nusantara Community, whereas the teacher is from Trisoka Community. It did not impede the learning intention since the material is taken from the outline of the community of penghayat kepercayaan in Indonesia.

In terms of a national examination, the students of penghayatkepercayaan take the exam as other students do. The teacher makes the exam questions given by penghayat kepercayaan, which are then submitted to the school. Then, for the final school exams, questions were also 
made by penghayat kepercayaan teachers. Questions are made based on the material they have learned.

Students of penghayat kepercayaan at SMK Negeri 1 Kasihan have never been treated unfavourably, such as discrimination from teachers or other students.

The school has a cultural background, and students who attend school are not only originally from Yogyakarta but also from various regions in Indonesia. Therefore, diversities have become commonplace for the schools. Students, teachers, and the school community respect each other's differences and build a high tolerance for different beliefs.

\section{CONCLUSION}

In summary, the fulfillment of learning services for students of penghayat kepercayaan in Bantul Education Office refers to the policies of Regulation of the Minister of Education and Culture of the Republic of Indonesia Number 27 the Year 2016 on the Services of Education for Kepercayaan in God Almighty at any level of Educational Unit. The regulations state that students of penghayat kepercayaan have the right to get Kepercayaan of God the Almighty education Service following the rights of students by upholding human rights.

Students of penghayat kepercayaan in the Office of Education in the Bantul area have not received good services in learning religious education. It is proved by the absence of an exact curriculum and the unavailability of textbooks to support learning.

The teacher of Aliran Kepercayaan education is not from the same community in which the students' background. Nevertheless, it is not a barrier to implementing the teachinglearning process. The local government has not acted quickly in dealing with this issue.

Based on the Regulation of the Ministry of Education and Culture of the Republic of Indonesia Number 27 for the Year 2016 on Service of Kepercayaan Education of God Almighty in Unit of Education, the fulfillment of students' services is still inappropriate.

\section{ACKNOWLEDGEMENT}

The authors would like to thank the head of the Bantul Education Office, Yogyakarta, Indonesia, for allowing us to conduct research on the unofficial religious group in Indonesia. Hence, a lot of gratitude for the Center of Research, Community Service of Universitas PGRI Yogyakarta (LPPM UPY), and AJIB Team.

\section{REFERENCES}

Amal Al-Aamri ,Rohana Jani, Yong Zulina Zubairi. 2020. A Review Of Models And Techniques Used To Gauge Quality In Higher Education. J. $\quad$ Ponte - Jan $2020 \quad-\quad$ Volume 76 - $\quad$ Issue 1. doi: 10.21506/j.ponte.2020.1.15. http://www.pontejournal.net/mainpanel/abstract.php?TOKEN=gRkgF 5411G\&PID=PJ-ZUPJ9

Cletus Famous Nwankwo, Romanus U. Ayadiuno, Alphonsus N. Ali, Ignatius A. Madu. 2020. FarmerHerder Conflict: The Politics Of Media Discourse In Nigeria. J. Ponte - Jan 2020 - Volume 76 - Issue 1. doi: 10.21506/j.ponte.2020.1.13.http://www.pontejournal.net/mainpanel/ab stract.php?TOKEN=gRkgF5411G\&PID=PI-TKM2I

Dian, Kurnia. 2018. "Nasionalisme Sebagai Ajaran Spritual Penghayat". KONTEMPLASI Jurnal Ilmu-ilmu Ushuludin, 6(1).

Elliot, A.J. \& Church, M.A. 1997. "A Hierarchical Model of Approach and Avoidance Achievement Motivation." Journal of Personality and Social Psychology, 72: 218-232.

Emmanuel, A-O., Adom, E.A., Josephine, B., \& Solomon, F.K. 2014. "Achievement Motivation, Academic Self-Concept And Academic Achievement Among High School Students." European Journal of Research and Reflection in Educational Sciences. 2(2): 24-37.

Ergul, H. 2004. "Relationship Between Student Characteristics and Academic Achievement in Distance 383 | P a g e 
Education and Application on Students of Anadolu University." Turkish Online Journal of Distance Education, 5(2): 81-90.

Frietas, K.S. \& Lynch,P. (1986). Factors affecting student success at the National Open University of Venezuela. An International Journal of Distance Education, 7, (2), 191-200.

Lickona, Thomas. 2013. Pendidikan Karakter; Panduan Lengkap Mendidik Siswa Menjadi Pintar dan Baik. Bandung: Nusa Media.

Gerard Effeney, Annemaree Carroll, \& Nan Bahr. 2013 Self-Regulated Learning: Strategi utama dan sumbernya dalam sampel remaja pria. Jurnal Australia Pendidikan \& Psikologi Perkembangan. Vol 13, 2013, hlm. 58-74

Gerard Effeney,Annemaree Carroll,\& Nan Bahr. 2013. Self-Regulated Learning: Key strategies and their sources in a sample of adolescent males. Australian Journal of Educational \& Developmental Psychology. Vol 13, 2013, pp. 58-74

Guri A. Nortvedt. 2020. Aiding culturally responsive assessment in schoolsin a globalising world. Educational Assessment, Evaluation and Accountability (2020) 32:527https://doi.org/10.1007/s11092-020-09316-w. https://link.springer.com/content/pdf/10.1007\%2Fs11092-020-09316-w.pdf

Kang'ahi, M., Indoshi, F.C., Okwach, T.O. \& Osodo, J. 2012. "Teaching Styles and Learners' Achievement in Kiswahili Language in Secondary Schools." International Journal of Academic Research in Progressive Education and Development, 1(3): 62-87.

Lana Šojat. 2020. Initial Beliefs of Preservice Chemistry Teachers in Croatia. Center for Educational Policy Studies Journal, doi: 10.26529/cepsj.730

Maureen Hannay, Tracy Newvine. 2006. Perceptions of Distance Learning : A Comparison of Online and Traditional Learning. MERLOT Journal of Online Learning and Theacing. Volume 2/No. 1/March 2006. Hlm. 1-11.

Muwaffiq, dan Mukhlish. 2019. "Akibat Hukum Pemisahan Hak Beragama dengan Hak Berkepercayaan dalam Undang-Undang Dasar Negara Republik Indonesia Tahun 1945”. Jurnal Konstitusi 16 (2)

Odundo, P.A. \& Gunga, S.O. 2013. "Effects of Aplication of Instructional Methods on Learner Achievement in Business Studies in Secondary Schools in Kenya." International Journal of Education and Research, 1 (5): 1-22.

Peraturan Bersama Menteri Dalam Negeri Dan Menteri Kebudayaan Dan Pariwisata Nomor 43 Tahun 2009, Nomor 41 Tahun 2009 Tentang. Pedoman Pelayanan Kepada Penghayat Kepercayaan Terhadap Tuhan Yang Maha Esa.

Peraturan Menteri Agama Repulik Indonesia Nomor 16 Tahun 2010 Tentang Pengelolan Pendidikan Agama Di Sekolah.

Peraturan Menteri Pendidikan Dan Kebudayaan Republik Indonesia Nomor 27 Tahun 2016 Tentang Layanan Pendidikan Kepercayaan Terhadap Tuhan Yang Maha Esa Pada Satuan Pendidikan.

Ramon. Lewis et al.2008. Students' Reaction to Classroom Discipline in Australia,Israel, and China. Journal Teaching and Teacher Education 24 (2008) 715-724.

Septian Aji Permana ,Sucihatiningsih Dian Wisika Prajanti, Dewi Liesnoor Setyowati. 2016. JTC Management In Disaster Information System. J. Ponte - Dec 2016 - Volume 72 - Issue 12. doi: 10.21506/j.ponte.2016.12.51. http://www.pontejournal.net/mainpanel/abstract.php?TOKEN=gRkgF 5411G\&PID=PJ-W7WY4

Tella, J., Indoshi, F. C. \& Othuon, L. A. 2010. "Relationship between Students' Perspectives on the Secondary School English Curriculum and their Academic Achievement in Kenya." Journal of Educational Research, 1(9): 382-389.

Turner, E.A., Chandler, M., \& Heffer, R.W. 2009. "The Influence of Parenting Styles, Achievement Motivation, and Self-Efficacy on Academic Performance in College Students." Journal of College Student Development. 50 (3): 337-346.

Van-Wyk, M.M. 2012. "The Effects of the STAD-Cooperative Learning Method on Student Achievement, Attitude and Motivation in Economics Education." Journal of Social Science, 33(2): 261-270.

Widya, Dita. 2017. "Urgensi Pengaturan Perlindungan Hukum Bagi Penghayat Kepercayaan Dari Penghinaan Terhadap Aliran Kepercayaannya". Hukum Student Journal

Zakiyah. 2018. "Pendidikan Kepercayaan Terhadap Tuhan Yang Maha Esa: Pemenuhan Hak Siswa Penghayat Di Sekolah". Penamas Jurnal Penelitian Keagamaan Dan Masyarakat, 31(2). 
385 | P a g e 